\title{
Effects of Nitrogen and Phosphorus Fertilizer Rates on Growth, Yield and Yield Components of Okra (Abelmoschus Esculentus (L.) Monech) Under Rain fed Condition in Metekel Zone, Northwestern Ethiopia
}

\author{
Shambel Aseffa \\ Ethiopian Institute of Agricultural Research Pawe Agricultural Research Center, P.O.BOX 203 Addis Ababa, \\ Ethiopia \\ Asfaw Degu \\ Bahir Dar Universtiy College of Agriculture and Environmental Science \\ Tesfaye Abebe \\ Ethiopian Institute of Agricultural Research Holeta Agricultural research Center
}

\begin{abstract}
Yield and productivity of Okra (Abelmoschus esculentus L. (Moench)) in Ethiopia has been far below other developing country standards partly due to poor nutrient management practice. Thus, a field experiment was conducted at Pawe Agricultural Research Center during 2018 main growing season to determine the effects of Nitrogen $(\mathrm{N})$ and Phosphorus $(\mathrm{P})$ fertilizer rates on growth, yield, yield components of Okra under Pawe conditions, Northwestern Ethiopia. The treatments consisted of factorial combinations of four levels of Nitrogen $(0,50,100$ and $150 \mathrm{~kg} / \mathrm{ha}$ ) and four levels of Phosphorus $(0,37.5,75$ and $112.5 \mathrm{~kg} / \mathrm{ha})$ that were laid out in a Randomized complete Block Design with three replications. Results of this study revealed that $\mathrm{N}$ and $\mathrm{P}$ had a highly significant effect on growth, yield and yield components such as plant height, branch number, node number, number of leaves per plant, leaf area, pod number per plant, average fruit weight, total fruit number per plot and fruit yield. The highest total fruit yield of $11.47 \mathrm{t} /$ ha was recorded from treatment combination of $\mathrm{N}$ and $\mathrm{P}$ at the rate of 50 and $37.5 \mathrm{~kg} / \mathrm{ha}$, respectively. The maximum $(150 \mathrm{~kg} / \mathrm{ha})$ Nitrogen rate resulted in luxuriant vegetative growth, reduced fruit number per plant, while application of phosphorus significantly increased fruit number per plant, fruit number per plot, total fresh fruit yield. According to the partial budget analysis, the highest net benefit (153958.16 ETB per hectare) was recorded from the combined applications of $\mathrm{N}$ and $\mathrm{P}$ at the rate of $50: 37.5 \mathrm{~kg} / \mathrm{ha}$. Nevertheless, since this is a one season result at one location more researches are needed in different locations on different representative soils for more seasons to reach at conclusive fertilizer recommendation for this specific crop in the area.
\end{abstract}

Keywords: Nitrogen, Okra, Phosphorus, Pod yield

DOI: $10.7176 / \mathrm{JBAH} / 10-11-05$

Publication date:June $30^{\text {th }} 2020$

\section{Introduction}

Okra (Abelmoschus esculentus L. (Moench)) is economically important vegetable crop grown in tropical and subtropical parts of the world for its immature pods. It is presumed to be originated in Ethiopia, but now spread and widely grown in Africa, especially in Sudan, Egypt and Nigeria (Aladele et al., 2008) and Asia, Central and South America (Khan et al., 2000; Naheed et al., 2013). Globally, Okra occupied a total area of 2,402,036 ha in 2017 (FAOSTAT, 2017). A sum of 9.64 million metric tons (MT) was harvested with an average yield 4.01 MT/ha. More than $99 \%$ of Okra cultivation is in the developing countries of Asia and Africa. India stands first in the world with a production of 6.0 million MT $(62.26 \%$ of the total world production) from approximately 0.5 million hectare of land with an average productivity of $11.84 \mathrm{MT} / \mathrm{ha}$ (FAOSTAT, 2017).

The crop associations with the native food in different regions of the country creates a great stable demand for it (Naim and Abker, 2016). The immature tender pods are used in stews or cut into slices, sundried, and ground as a powder to be used as a favorite dish. Similarly, the older immature pods which start to develop fiber are also cut into slices, sundried, ground and cooked. Even the young leaves are used as a vegetable and also dried form (Naim and Abker, 2016). Okra mucilage has medicinal applications when used as a plasma replacement or blood volume expander (Gemede et al., 2015). The mucilage of Okra binds cholesterol and bile acid carrying toxins dumped into it by the liver (Gemede et al., 2015). Despite its nutritional compositions, Okra pod is a powerhouse of valuable nutrients (Hassan and Ali, 2015) and affordable source of protein, carbohydrates, minerals, vitamins, and dietary fiber (Gemede et al., 2015). Thus, it is vital to promote the use of indigenous vegetables like Okra that has such significant role in mitigate food insecurity and alleviate malnutrition especially among resourceconstrained households and can also be used as a means of dietary diversification in the country. 
The agro-climatic conditions of Ethiopia are quite favorable both for home garden and commercial farming. However, it is a neglected crop and only known and grown in a few parts of the country like Humera, Gambella, and Benshangul Gumuz. Okra is one of the most important crops next to maize and sorghum production in Gambella Regional States (Baw et al., 2017). It is also highly important in Benishangul Gumuz and highly preferred \& consumed by the native people. However, it grows conventionally and no attention has so far been given for the development of improved agronomic management practices (Zibelo et al., 2016). Information on its production area and productivity is generally unavailable under Ethiopian condition though known to have high diversity in some parts of the country particularly in the Southwestern low lands (Baw et al., 2017) and Northwestern part of the country. According to the Ethiopian Investment Agency (2012) report Okra is considered as recently emerged important export vegetable crops. But, the productivity of Okra is very low compared to other countries like India (11.84 MT/ha) and other developing countries (6.46 MT/ha) of the world (Firoz, 2009).

Being a minor crop in Benishangul Gumuz, farmers, development agents and even researchers are not aware of its basic agronomy and growing requirements. As a result the effect of nutrient management on growth and yield of Okra has not been examined in the target area. Farmers grow the crop around their homestead devoid of any more cultivation and nutrient application except animal manures which was collected from their cattle. Keeping in mind the potential of the crop and the low yield farmers are getting in Metekel area, it is of utmost importance to conduct and develop optimal agronomic management practices such as nutrient management for the crop. The present study was therefore designed to evaluate the effects of nitrogen and phosphorus fertilizer rates on growth, yield and yield component of Okra and to determine economically optimum rates of nitrogen and phosphorus for better growth and yield of Okra

\section{Materials and Methods}

\subsection{Description of the Study Area}

The experiment was conducted during rainy season of 2018 at Pawe Agricultural research center. The experimental site is located within latitude $11^{0} 18^{\prime} 49.6^{\prime \prime} \mathrm{N}$ of the Equator and longitude $036^{0} 24^{\prime} 29.1^{\prime \prime} \mathrm{E}$ of Greenwich, which is found in Benshangul Gumuz regional state in Metekel Zone. It is located about $570 \mathrm{~km}$ away from Addis Ababa, the capital city of Ethiopia. The altitude of the area is 1120 meter above sea level. The site receives an annual rainfall $1507.7 \mathrm{~mm}$; however, the rainfall is erratic and concentrated in only a few months of the year mainly starts from May to November. The mean annual maximum and minimum temperatures of the area are $33.26^{\circ} \mathrm{c}$ and 17.13 ${ }^{0} \mathrm{c}$, respectively as shown in Table 1 .

\subsection{Experimental Material, Treatments and Design}

One genotype (M-27c) was used for this experiment. Seeds used for this study was obtained from the Melkassa Agricultural Research Center. Genotype M-27c is presently under variety trial. The genotype displayed superior performance in yield than the rest accessions in the study area.

Table 3. Meteorological information in Pawe, Ethiopia (January - December) 2018

\begin{tabular}{|c|c|c|c|c|}
\hline \multirow[t]{2}{*}{ Month } & \multirow{2}{*}{$\begin{array}{l}\text { Monthly Rainfall } \\
(\mathrm{mm})\end{array}$} & \multicolumn{2}{|c|}{ Average Temperature $\left({ }^{\circ} \mathrm{C}\right)$} & \multirow[t]{2}{*}{ Average Relative Humidity (\%) } \\
\hline & & Minimum & Maximum & \\
\hline January & 0 & 12.6 & 34.4 & 66 \\
\hline February & 0 & 16.7 & 38.0 & 64 \\
\hline March & 0 & 17.0 & 38.2 & 60 \\
\hline April & 0 & 18.5 & 38.0 & 65 \\
\hline May & 170.7 & 19.8 & 37.0 & 65 \\
\hline June & 315.7 & 19.0 & 29.9 & 86 \\
\hline July & 338.2 & 18.0 & 28.8 & 86 \\
\hline August & 339.9 & 17.7 & 28.6 & 89 \\
\hline September & 131.0 & 17.7 & 30.1 & 87 \\
\hline October & 142.2 & 17.8 & 30.5 & 86 \\
\hline November & 70.0 & 15.9 & 32.3 & 85 \\
\hline December & 0 & 14.9 & 33.4 & 83 \\
\hline
\end{tabular}

\section{Source: Ethiopian Institute of Agricultural Research Agro-meteorological Service}

The fertilizer treatments consist of four levels of nitrogen $(0,50,100$, and $150 \mathrm{~kg} / \mathrm{ha})$ and four levels of phosphorus $(0,37.5,75$, and $112.5 \mathrm{~kg} / \mathrm{ha})$. Urea $(46 \% \mathrm{~N})$ and triple super phosphate, TSP $\left(46 \% \mathrm{P}_{2} \mathrm{O}_{5}\right)$ were used as fertilizers sources for nitrogen and phosphorus, respectively (Jones, 2002). The treatments were arranged in a randomized complete block design (RCBD) with three replications in factorial arrangement and the plot has four rows each containing six plants per row.

\subsection{Experimental Procedures}

The experimental site was disc ploughed, disc harrowed and leveled out to maintain a well leveled seed bed and 
then followed by ridging between ridges which was oriented in perpendicular to the slope gradient. Individual plot size $2.7 \mathrm{~m} \times 2.8 \mathrm{~m}$ consisting of four ridges of 2.7 meters in length and the net plot area of the experimental field was $2.52 \mathrm{~m}^{2}$.

Sowing was done manually at the center of the ridge by putting 2 seeds per hill with $45 \mathrm{~cm} \mathrm{X} 70 \mathrm{~cm}$ apart between plant and between rows respectively, and it was carried out on $29^{\text {th }}$ June, 2018. The entire amount of TSP in the experiments was applied at the time of final land preparation. Urea was applied in two equal installments as top dressing. First and second round Urea applications were practiced as top dressing around the plant and incorporate with soil at $3^{\text {rd }}$ and $5^{\text {th }}$ week after seedling emergence. Necessary cultural operations were delivered through the cropping season for proper growth and development of the plant.

\subsection{Data Collections}

Phenological, growth and yield parameter of Okra were recorded from the net plot area using the standard procedures. Plant height was recorded at the time of last fresh edible pod harvest from the ground level to the terminal bud from five randomly selected plant using a measuring tape. Number of leaves per plant, number of nodes per plant and number of branches per plant were recorded at 90 day after sowing by counting the number of leaves, primary nodes $\&$ number of branches from randomly and tagged five plants.

Harvesting of fruit continues every four days until the rain has been stopped since immature fruits are ready for fresh-market harvest between 4 and 6 days after anthesis. After the $7^{\text {th }}$ day, fibrousness of the pods increases rapidly, rendering them inedible. Number of pods per plant, pod fresh weight, pod length, fruits diameter and average fruit weight were recorded from the net plot area of the experiment and finally the weights of previously harvested pods per plot were sum up to get the plot yield per unit area. Then, the equivalent yield in $t / h a$ was calculated and used for further analysis.

\subsection{Data Analysis}

The collected data was subjected to Analysis of variance (ANOVA) using SAS computer software. Mean separation were done by List Significance Difference (LSD) test at 5\% probability level depending on the results of ANOVA as indicated by Gomez and Gomez (1984).

Soil sampling and analysis

A representative samples were taken before planting in zigzag walking manner and captures its heterogeneity and reduces error from a depth of $0-30 \mathrm{~cm}$ of the cultivable profile. The soil samples were analyzed in Pawe Agricultural Research Center Soil Laboratory and the result described in Table 2.

Table 4. Soil physical and chemical properties before planting

\begin{tabular}{ll}
\hline Soil parameters & Values \\
\hline pH & 5.24 \\
Organic matter $(\%)$ & 4.10 \\
Organic carbon $(\%)$ & 2.38 \\
Total nitrogen $(\%)$ & 0.186 \\
Available P $(\mathrm{mg} / \mathrm{kg})$ & 1.81 \\
Sand $(\%)$ & 2 \\
Silt $(\%)$ & 20 \\
Clay $(\%)$ & 78 \\
Class & Clay \\
\hline
\end{tabular}

\section{Results and discussions}

The results of analysis revealed the significant effects of tested fertilizer rates on growth, phenological, yield and yield related parameters considered. The details of these results are presented as follows.

3.1. Effect of Nitrogen and Phosphorus Fertilizer Rates on Phenological and Growth Parameters of Okra

3.1.1. Plant height

Analysis of data showed that application of nitrogen and phosphorus fertilizer rates had a significant effect on plant height of Okra (Table 3). None significant differences were observed due to interaction effect of nitrogen and phosphorus levels on plant height. The maximum plant height $(122.33 \mathrm{~cm})$ was recorded from treatment plot received $50 \mathrm{~kg} / \mathrm{ha}$ nitrogen, while the minimum plant height $(97.90 \mathrm{~cm})$ was recorded from the control plot. Application of $50 \mathrm{~kg} / \mathrm{ha} \mathrm{N}$ increased plant height by $24.95 \%$ compared to the control plot (Table 3 ). However, increase in the rate of nitrogen beyond 50 to 100 and $150 \mathrm{~kg} \mathrm{~N} /$ ha resulted in a significant reduction in plant height by $8.46 \%$, as compared to $50 \mathrm{~kg} / \mathrm{ha} \mathrm{N}$ application although responses of 100 and $150 \mathrm{~kg} \mathrm{~N} / \mathrm{ha}$ was statistically identical and significantly differed from the other two rates of nitrogen. The higher rate of $\mathrm{N}$ might have enhanced cell division and formation of more tissues resulting in luxuriant vegetative growth and thereby increased plant height (Firoz, 2009). The observed increase in mean plant height at increased application of $\mathrm{N}$ could be attributed to its involvement as building blocks in the synthesis of amino acids which is link with the formation of proteins 
required for plant growth. This result agrees with Bin-Ishaq (2009) who reported that increasing the rate of $\mathrm{N}$ up to $45 \mathrm{Kg} \mathrm{N} / \mathrm{ha}$ is associated with significant progressive increases in plant height of Okra. (Baw et al., 2017) also reported maximum plant height from treatment that receives nitrogen at the rate of $23 \mathrm{~kg} / \mathrm{ha}$.

The highest plant height also $\left(113.22 \mathrm{~cm}\right.$ ) recorded from treatment received $\mathrm{P}_{2} \mathrm{O}_{5}$ at a rate of $75 \mathrm{~kg} / \mathrm{ha}$. All rates of $\mathrm{P}_{2} \mathrm{O}_{5}$ significantly increased plant height over the control plot but produced statistically identical result compared with each other (Table 3). Significant increase in growth parameters with the application of phosphorus may be attributed to the phosphorus involvement in energy transformation in plant cells, cell division, development of meristematic tissues, early root development and branching (Firoz, 2009). Kumar and Singh, (2015) found highest plant height $(117.94 \mathrm{~cm})$ from the application of $90 \mathrm{~kg} / \mathrm{ha}$ phosphorus fertilizer rates which is in agreement with this finding.

Table 5. Main effect of nitrogen and phosphorus on plant growth characters of okra

\begin{tabular}{|c|c|c|c|c|c|}
\hline $\begin{array}{l}\text { Treatment } \\
\text { Nitrogen } \\
\end{array}$ & Plant height $(\mathrm{cm})$ & Branch/plant & Leaves/plant & Leaf area & $\begin{array}{l}\text { Number of } \\
\text { nodes }\end{array}$ \\
\hline 0 & $97.9^{c}$ & $1.47^{b}$ & $15.78^{\mathrm{c}}$ & $338.83^{c}$ & $10.42^{\mathrm{c}}$ \\
\hline 50 & $122.33^{\mathrm{a}}$ & $1.75^{\mathrm{a}}$ & $20.52^{\mathrm{a}}$ & $483.81^{\mathrm{a}}$ & $12.03^{\mathrm{a}}$ \\
\hline 100 & $111.65^{b}$ & $1.73^{\mathrm{a}}$ & $18.53^{\mathrm{b}}$ & $417.32^{b}$ & $11.52^{\mathrm{b}}$ \\
\hline 150 & $111.97^{b}$ & $1.57^{\mathrm{ab}}$ & $18.23^{\mathrm{b}}$ & $425.07^{\mathrm{b}}$ & $11.05^{\mathrm{b}}$ \\
\hline \multicolumn{6}{|l|}{ Phosphorus } \\
\hline 0 & $106.367^{b}$ & $1.33^{b}$ & $16.43^{b}$ & $369.71^{b}$ & $10.73^{b}$ \\
\hline 37.5 & $111.917^{\mathrm{a}}$ & $1.73^{\mathrm{a}}$ & $19.73^{\mathrm{a}}$ & $393.16^{b}$ & $11.28^{\mathrm{a}}$ \\
\hline 75 & $113.217^{\mathrm{a}}$ & $1.79^{\mathrm{a}}$ & $18.57^{\mathrm{a}}$ & $452.79^{a}$ & $11.59^{\mathrm{a}}$ \\
\hline 112.5 & $112.350^{\mathrm{a}}$ & $1.66^{\mathrm{a}}$ & $18.33^{\mathrm{a}}$ & $449.37^{\mathrm{a}}$ & $11.42^{\mathrm{a}}$ \\
\hline LSD at $5 \%$ & 5.13 & 0.22 & 1.45 & 33.89 & 0.48 \\
\hline $\mathrm{CV}$ & 5.5 & 16.48 & 9.5 & 9.76 & 5.1 \\
\hline
\end{tabular}

*Means followed by the same letter (s) in the same column are not significantly different at $5 \%$ level of significance; bran $/$ plant $=$ number of branches per plant

3.1.2. Number of leaves per plant

Number of leaves per plant at 90 days after sowing significantly affected by main factor nitrogen, phosphorus and there interaction effect of nitrogen and phosphorus fertilizer rates (Table 3). Significantly higher number of leaves per plant (23.67) were recorded from a combined application of $50 \mathrm{~kg} / \mathrm{ha} \mathrm{N}$ together with $37.5 \mathrm{~kg} / \mathrm{ha} \mathrm{P}_{2} \mathrm{O}_{5}$ followed by $100 \mathrm{~kg} / \mathrm{ha} \mathrm{N}$ with $112.5 \mathrm{~kg} / \mathrm{ha} \mathrm{P}_{2} \mathrm{O}_{5}$ (20.73) (Table 4). The increased number of leaves per plant may be due to the fact that application of nitrogen and phosphorus accelerate the synthesis of chlorophyll and amino acids which are associated with major plant processes. The number of leaves produced by a plant is directly proportional to the photosynthates produced. This is because leaves are the place of photosynthetic activities of crops through which biomass are produced, partitioned among various parts of crops and stored for crop productivity. Abebe \& Feyisa, (2017) indicated that when photosynthesis becomes active in a young seedling, the power of the plant to synthesize new materials is clearly dependent on the amount of leaves exposed to direct sunlight. The higher the number of leaves, the higher the rate of photosynthesis with subsequent increase in carbohydrate production and hence increase in food production. On the other hand, fewer leaves means a lower LAI, resulting in less light interception and, hence, a lower total biomass production. The result obtained in the present study agreed with that of (Khan et al., 2000) who reported maximum number of leaves recorded from the application of $120 \mathrm{~kg} \mathrm{~N}+60 \mathrm{~kg} \mathrm{P}_{2} \mathrm{O}_{5} / \mathrm{ha}$. 3.1.3. Leaf area

Leaf area per plant was significantly $(\mathrm{P}<0.001)$ affected by nitrogen and phosphorus fertilizer application. However, the interaction effects of nitrogen and phosphorus fertilizer showed non-significant effect on leaf area per plant. Treatment received $50 \mathrm{~kg} /$ ha nitrogen produced the highest leaf area per plant $\left(483.81 \mathrm{~cm}^{2}\right)$ followed by $150 \mathrm{~kg} / \mathrm{ha} \mathrm{N}\left(425.07 \mathrm{~cm}^{2}\right)$ (Table 3) and the control plot produced the lowest leaf area per plant $\left(338.83 \mathrm{~cm}^{2}\right)$. It is suggested that cytokinin may play a role in leaf elongation either cell division or cell elongation, as the increase of leaf area following fertilization may be due to an increase in availability of cytokinin in the shoots, which is normally produced in root tips. This result agrees with Kumar and Singh (2015) who reported that application of $90 \mathrm{~kg} / \mathrm{ha} \mathrm{N}$ produced maximum leaf area per plant $\left(784.13 \mathrm{~cm}^{2}\right)$. Application of nitrogen fertilizer rates beyond 50 $\mathrm{kg} / \mathrm{ha}$ showed a decline effects on leaf area per plant in Okra (Table 3). This was due to the fact that excessive application nitrogen fertilizer in the form of urea had a soil acidifying effects and thus results significantly influence the nutrient availability in the soil.

The highest leaf area $\left(452.79 \mathrm{~cm}^{2}\right)$ was recorded from $75 \mathrm{~kg} / \mathrm{ha} \mathrm{P}_{2} \mathrm{O}_{5}$ closely followed by treatment received $112.5 \mathrm{~kg} / \mathrm{ha} \mathrm{P}_{2} \mathrm{O}_{5}\left(449.37 \mathrm{~cm}^{2}\right)$ which was statistically at par with each other but statistically different from treatment that received $37.5 \mathrm{~kg} / \mathrm{ha} \mathrm{P}_{2} \mathrm{O}_{5}$ and to the control plot (Table 3). This is may be due to the reason that phosphorus is essential in several bio-chemicals that control photosynthesis, respiration, cell division, and many other plant growth and development processes. This result is in agreement with the finding of Kumar \& Singh, (2015) who observed maximum leaf area $\left(784.85 \mathrm{~cm}^{2}\right)$ were produced from treatment received $90 \mathrm{~kg} / \mathrm{ha} \mathrm{P}_{2} \mathrm{O}_{5}$. 
Table 6. Interaction effect of nitrogen and phosphorus on selected plant growth parameters of okra

\begin{tabular}{llll}
\hline Treatment & Branches/plant & leaves/plant & Number of nodes/plant \\
\hline & & & \\
N1P1 & $1.33^{\mathrm{c}-\mathrm{e}}$ & $15.93^{\mathrm{f}-\mathrm{i}}$ & $9.73 \mathrm{~g}$ \\
N1P2 & $1.47^{\mathrm{cd}}$ & $16.4^{\mathrm{e}-\mathrm{i}}$ & $10.93 \mathrm{c}-\mathrm{f}$ \\
N1P3 & $2.1^{\mathrm{ab}}$ & $16.6^{\mathrm{d}-\mathrm{i}}$ & $10.7 \mathrm{ef}$ \\
N1P4 & $1.0^{\mathrm{e}}$ & $14.2^{\mathrm{i}}$ & $10.3 \mathrm{fg}$ \\
N2P1 & $1.33^{\mathrm{c}-\mathrm{e}}$ & $18.53^{\mathrm{b}-\mathrm{g}}$ & $12.33 \mathrm{ab}$ \\
N2P2 & $2.27^{\mathrm{a}}$ & $23.67^{\mathrm{a}}$ & $12.4 \mathrm{ab}$ \\
N2P3 & $1.67^{\mathrm{b}-\mathrm{d}}$ & $20.4 \mathrm{~b}^{\mathrm{c}}$ & $12.6 \mathrm{ab}$ \\
N2P4 & $1.73^{\mathrm{bc}}$ & $19.47^{\mathrm{b}-\mathrm{d}}$ & $10.8 \mathrm{~d}-\mathrm{f}$ \\
N3P1 & $1.40^{\mathrm{c}-\mathrm{e}}$ & $15.53^{\mathrm{hi}}$ & $10.66 \mathrm{e}-\mathrm{g}$ \\
N3P2 & $1.60^{\mathrm{cd}}$ & $20.20^{\mathrm{bc}}$ & $11.0 \mathrm{c}-\mathrm{f}$ \\
N3P3 & $1.67^{\mathrm{b}-\mathrm{d}}$ & $17.67^{\mathrm{c}-\mathrm{h}}$ & $11.7 \mathrm{~b}-\mathrm{d}$ \\
N3P4 & $2.23^{\mathrm{a}}$ & $20.73^{\mathrm{b}}$ & $12.73 \mathrm{a}$ \\
N4P1 & $1.27^{\mathrm{de}}$ & $15.73^{\mathrm{g}-\mathrm{i}}$ & $10.2 \mathrm{fg}$ \\
N4P2 & $1.60^{\mathrm{cd}}$ & $18.67^{\mathrm{b}-\mathrm{f}}$ & $10.8 \mathrm{~d}-\mathrm{f}$ \\
N4P3 & $1.73^{\mathrm{bc}}$ & $19.6^{\mathrm{bc}}$ & $11.36 \mathrm{c}-\mathrm{e}$ \\
N4P4 & $1.67^{\mathrm{b}-\mathrm{d}}$ & $18.93^{\mathrm{b}-\mathrm{e}}$ & $11.86 \mathrm{a}-\mathrm{c}$ \\
\hline LSD at 5\% & $\mathbf{0 . 4 4 7}$ & $\mathbf{2 . 8 9}$ & $\mathbf{0 . 9 5}$ \\
\hline CV & $\mathbf{1 6 . 4 8}$ & $\mathbf{9 . 5}$ & $\mathbf{5 . 1}$ \\
\hline
\end{tabular}

*Means followed by the same letter (s) in the same column are not significantly different at 5\% level of significance, ns= non-significant

3.1.4. Branch number per plant

Primary branch number per plant were significantly affected by the interaction of nitrogen and phosphorus fertilizer application and the maximum values were recorded from the combination of $\mathrm{N}$ and $\mathrm{P}_{2} \mathrm{O}_{5}$ at the rate of 50 with $37.5,100$ with 112.5 and 0 with $75 \mathrm{~kg}$ /ha resulted maximum number of branches per plant 2.27, 2.23 and 2.1 respectively. The lowest number of branches were recorded from treatment plots of $\mathrm{N}$ and $\mathrm{P}$ at the rate of 0 with $112.5 \mathrm{~kg} / \mathrm{ha}$ (1.0) (Table 4). This is because nitrogen is the fundamental part of the chlorophyll molecule and essential in the formation of amino acids, which are the building blocks of all proteins including enzymes, which control virtually all biological processes. Besides, phosphorus stimulates cell division, elongation as well as flowering and fruit set. This finding was in conformity with the work of Khandaker et al., (2017) who reported that the highest number of branches (7) per plant recorded form the highest rate of NPK fertilizer rates. Depending on the cultivar used the environmental condition and soil factors the number of branches per plant completely different.

\subsection{Effect of Nitrogen and Phosphorus on Yield and Yield Components of Okra}

3.2.1. Number of fruits per plant

Number of fruits per plant were significantly $(\mathrm{P}<0.001)$ affected by the interaction effects of nitrogen and phosphorus fertilizer application and the maximum number of fruits (20.6 and 19.7) were recorded from treatment received $75 \mathrm{~kg} / \mathrm{ha}$ phosphorus alone and $50 \mathrm{~kg} / \mathrm{ha} \mathrm{N}$ with $37.5 \mathrm{~kg} / \mathrm{ha} \mathrm{P}_{2} \mathrm{O}_{5}$ respectively and this is statistically similar. The lowest number of fruits per plant (12.1) were recorded from treatment received $50 \mathrm{~kg} / \mathrm{ha}$ nitrogen alone which was statistically at par with those plots fertilized by $50 \mathrm{~kg} / \mathrm{ha} \mathrm{N}$ with $112.5 \mathrm{~kg} / \mathrm{ha}_{2} \mathrm{O}_{5}$ (Table 6). The number of fruits per plant is an important factor to increase the yield of Okra (Paththinige et al., 2008). Number of fruits per plant depends upon the number of branches per plant, as more branches were observed in plot fertilized with optimum amounts of $\mathrm{N}$ and $\mathrm{P}_{2} \mathrm{O}_{5}$ at the rate of 50 and $37.5 \mathrm{~kg} /$ ha which ultimately gave higher number of fruits per plant. This was probably because plants that received $50 \mathrm{~kg} / \mathrm{ha} \mathrm{N}$ with $37.5 \mathrm{~kg} / \mathrm{ha}_{2} \mathrm{O}_{5}$ produces greater amount of branches, thus resulting in higher number of green pods per plant. This result was in line with Meena et al. (2017) who reported that maximum pod number per plant recorded from combined application of N P K at the rate of $9060 \& 60 \mathrm{~kg} / \mathrm{ha}$, respectively.

3.2.2. Fruit length and diameter

The ANOVA table of the present study showed that both pod length and width were significantly $(\mathrm{P}<0.01)$ affected by the interactions effects of nitrogen and phosphorus fertilizers. The longest pods $(11.43 \mathrm{~cm})$ were recorded from $\mathrm{N}$ and $\mathrm{P}_{2} \mathrm{O}_{5}$ treatments at the rate of 50 and $0 \mathrm{~kg} / \mathrm{ha}$ which was statistically at par with treatments of $\mathrm{N}_{\text {and }} \mathrm{P}_{2} \mathrm{O}_{5}$ at the rate of $50 \& 37.5,100 \& 112.5,100 \& 0,100 \& 75$ and $50 \& 75 \mathrm{~kg} / \mathrm{ha}$ and the shortest pods $(9.31 \& 9.9 \mathrm{~cm})$ were recorded from treatments of $\mathrm{N} \& \mathrm{P}_{2} \mathrm{O}_{5}$ at the rate of 150 and $0 \mathrm{~kg} / \mathrm{ha}$ and from the control plot, respectively (Table 6). Pod length is a quality character for economic yield which depends upon various factors such as genetic makeup of the cultivars and their response to prevailing environmental conditions. A study conducted by Paththinige et al., (2008) in Sri Lanka indicated that fruits having 15-20cm length are reported to have the highest 
market demand and consumer preference while post-harvest losses are minimal when compared to larger fruit size. This result is in line with the finding of Khan et al., (2013) who reported that longest pods $(17.97 \mathrm{~cm})$ were recorded from $\mathrm{N}$ and $\mathrm{P}$ treatments at the rate of 100 and $120 \mathrm{~kg} / \mathrm{ha}$ and shortest pods $(15.35 \mathrm{~cm})$ were there in control plots.

3.2.3. Average fruit weight

The main factors of nitrogen and phosphorus fertilizer application showed highly significant effects on average fruit weight of Okra (Table 5). Like that of the main factors, interaction effects also showed significant $(\mathrm{P}<0.01)$ difference in average fruit weight. The maximum average fruit weight $(24.37 \mathrm{~g})$ was recorded from treatment combination of $50 \mathrm{~kg} / \mathrm{ha} \mathrm{N}$ with $37.5 \mathrm{~kg} / \mathrm{ha} \mathrm{P}_{2} \mathrm{O}_{5}$ and the minimum (19.03 g) was recorded from treatments of $\mathrm{P}_{2} \mathrm{O}_{5}$ at the rate of $112.5 \mathrm{~kg} / \mathrm{ha}$ without nitrogen and the control plot (Table 6). Treatments that received $\mathrm{N}_{\text {and }} \mathrm{P}_{2} \mathrm{O}_{5}$ at the rate of 50 and $37.5 \mathrm{~kg} /$ ha produced 28.06 percent average weight of each individual fruits higher than the other treatment combination including the control. This may be higher doses of $\mathrm{N}$ and $\mathrm{P}$ fertilizer causes drop of leaf, drop of pod and reduce the quality of Okra pod. The result is in line with Khandaker et al. (2017) who reported that Okra pod weight decreased with higher dose of NPK fertilizer.

3.2.4. Fruit yield ( $\mathrm{t} / \mathrm{ha})$

The main effect of nitrogen and phosphorus fertilizer and there interaction revealed significant $(\mathrm{P}<0.01)$ influence on fruit yield per hectare. The maximum fresh fruit yield $(11.47 \mathrm{t} / \mathrm{ha})$ were recorded under $50 \mathrm{~kg} \mathrm{~N}$ in combination with $37.5 \mathrm{~kg} \mathrm{P}_{2} \mathrm{O}_{5} /$ ha (Table 6). The minimum fruit yield $(5.41 \mathrm{t} / \mathrm{ha}$ ) were recorded from treatment received nitrogen alone at the rate of $150 \mathrm{~kg} / \mathrm{ha}$ which was statistically at par with treatments of $\mathrm{N}$ alone at the rate of 50 $\mathrm{kg} / \mathrm{ha}$ and the control plot. The treatment levels of $\mathrm{N}$ and $\mathrm{P}_{2} \mathrm{O}_{5}$ at the rate of 50 and $37.5 \mathrm{~kg} / \mathrm{ha}$ increased the yield by 66.7 percent over the control. The final yield of a crop is the expression of the combined effect of various yield components. Likewise, fruit yield of Okra is the product of different yield contributing characters, such as plant height, number of branches, number of nodes, number of pods and yield per plant, pod length, pod weight and pod diameter (Hossain and Olasantan, 2001). Green pod yield of Okra depends upon yield per plant and plant population with good growth stand.

The yield of Okra is directly correlated with the length and thickness of fruit and the number of fruits produced per plant. Though these factors are governed by the genetic constitution of the plant, the stage at which the fruit is plucked is equally important. The stage of picking is also important from the quality point of view of the fruit. So, application of nitrogen and phosphorus fertilizer rates up to a $50 \mathrm{~kg} \mathrm{~N}$ and $37.5 \mathrm{~kg} \mathrm{P}_{2} \mathrm{O}_{5}$ results in higher fruit yield depends upon the yield per plant due to more number of branches \& nodes, whereas shorter and less number of nodes per plant leads to less number of pods per plant that ultimately resulting in low fruit yield. The result indicated that both $\mathrm{N}$ and $\mathrm{P}$ application had remarkable influence on fruit yield per ha. The result is in line with Firoz (2009) who reported that highest yield of Okra was obtained from N and P at the dose of 100 and $120 \mathrm{~kg} / \mathrm{ha}$ and further increment beyond this rates reduced the fruit yield of Okra.

Table 7. Main effect of nitrogen and phosphorus on yield and yield components of Okra

\begin{tabular}{|c|c|c|c|c|c|c|c|}
\hline$\frac{\text { Treatment }}{\text { Nitrogen }}$ & $\begin{array}{l}\text { Dates to } \\
\text { flowering }\end{array}$ & FNPP & TFNPP & $\begin{array}{l}\text { AFW } \\
(\mathrm{g})\end{array}$ & $\begin{array}{l}\text { Fresh fruit yield } \\
\text { t/ha }\end{array}$ & \multicolumn{2}{|l|}{$\begin{array}{l}\text { Biomass } \\
\text { (g)/plot }\end{array}$} \\
\hline $\mathbf{0}$ & $61.08^{\mathrm{b}}$ & $15.95^{\mathrm{a}}$ & $99.25^{\mathrm{a}}$ & $19.6^{\mathrm{b}}$ & $7.74^{\mathrm{bc}}$ & $1206.0^{\mathrm{b}}$ & \\
\hline 50 & $62.5^{\mathrm{a}}$ & $14.47^{\mathrm{b}}$ & $97.58^{\mathrm{a}}$ & $22.49^{a}$ & $8.8^{\mathrm{a}}$ & $2421.9^{\mathrm{a}}$ & \\
\hline 100 & $62.83^{\mathrm{a}}$ & $14.93^{\mathrm{ab}}$ & $94.58^{\mathrm{a}}$ & $22.5^{\mathrm{a}}$ & $8.46^{\mathrm{ab}}$ & $2266.9^{\mathrm{a}}$ & \\
\hline 150 & $62.67^{\mathrm{a}}$ & $14.51^{\mathrm{b}}$ & $87.0^{\mathrm{b}}$ & $21.93^{\mathrm{a}}$ & $7.59^{c}$ & $2194.7^{\mathrm{a}}$ & \\
\hline \multicolumn{8}{|l|}{ Phosphorus } \\
\hline $\mathbf{0}$ & $61.67^{\mathrm{b}}$ & $13.18^{\mathrm{c}}$ & $81.33^{\mathrm{c}}$ & $21.29^{\mathrm{bc}}$ & $6.91^{c}$ & $1826.0^{\mathrm{b}}$ & \\
\hline 37.5 & $62.67^{\mathrm{a}}$ & $16.53^{\mathrm{a}}$ & $110.16^{\mathrm{a}}$ & $22.23^{\mathrm{ab}}$ & $9.77^{\mathrm{a}}$ & $2033.4^{\mathrm{ab}}$ & \\
\hline 75 & $62.5^{\mathrm{a}}$ & $15.54^{\mathrm{ab}}$ & $93.67^{b}$ & $22.33^{\mathrm{a}}$ & $8.26^{\mathrm{b}}$ & $2250.3^{\mathrm{a}}$ & \\
\hline 112.5 & $62.25^{\mathrm{ab}}$ & $14.61^{\mathrm{b}}$ & $93.25^{\mathrm{b}}$ & $20.67^{\mathrm{c}}$ & $7.66^{\mathrm{b}}$ & $1979.7^{\mathrm{ab}}$ & \\
\hline LSD & 0.65 & 1.29 & 6.05 & 0.95 & 0.74 & 286.49 & \\
\hline $\mathbf{C V}$ & 1.26 & 10.38 & 7.68 & 5.26 & 10.9 & 16.99 & \\
\hline
\end{tabular}

*Means followed by the same letter (s) in the same column are not significantly different at $5 \%$ level of significance dates to $50 \%$ flowering, $\mathrm{FNPP}=$ fruit number per plant, TFNPP= total fruit number per plot, $\mathrm{AFW}=$ average fruit weight, yield/plot $=$ fresh fruit yield from the net plot area, yield/ha=fresh fruit yield in hectare base 
Table 8. Interaction effects of Nitrogen and phosphorus on yield and yield components of Okra

\begin{tabular}{|c|c|c|c|c|c|c|c|}
\hline \multirow[t]{2}{*}{ Treatment } & \multirow[t]{2}{*}{ FNPP } & \multirow[t]{2}{*}{ TFNPP } & \multicolumn{2}{|c|}{ Fruit $(\mathrm{cm})$} & \multirow[t]{2}{*}{$\mathrm{AFW}(\mathrm{g})$} & \multirow[t]{2}{*}{ Fresh fruit yield $t / h a$} & \multirow[t]{2}{*}{ Biomass yield (g) } \\
\hline & & & Length & Width & & & \\
\hline N1P1 & $12.77^{\mathrm{e}-\mathrm{g}}$ & $89.0^{\mathrm{e}}$ & $9.9^{\text {de }}$ & $1.81^{\mathrm{b}-\mathrm{f}}$ & $19.4^{\mathrm{e}}$ & $6.88^{\mathrm{gh}}$ & $1214.83^{\mathrm{gh}}$ \\
\hline N1P2 & $15.36^{\mathrm{b}-\mathrm{d}}$ & $107.0^{\mathrm{a}-\mathrm{c}}$ & $10.70^{\mathrm{a}-\mathrm{d}}$ & $1.85^{\mathrm{b}-\mathrm{e}}$ & $20.48^{\mathrm{de}}$ & $8.71^{\mathrm{b}-\mathrm{e}}$ & $1455.16^{\mathrm{f}-\mathrm{h}}$ \\
\hline N1P3 & $20.6^{\mathrm{a}}$ & $103.0^{\mathrm{b}-\mathrm{d}}$ & $10.60^{\mathrm{a}-\mathrm{d}}$ & $1.86^{\mathrm{b}-\mathrm{d}}$ & $19.5^{\mathrm{e}}$ & $7.98^{\mathrm{d}-\mathrm{g}}$ & $1261.83^{\mathrm{gh}}$ \\
\hline N1P4 & $15.06^{b-f}$ & $98.0^{\mathrm{c}-\mathrm{e}}$ & $10.19^{c-d}$ & $1.71^{\mathrm{ef}}$ & $19.03^{\mathrm{e}}$ & $7.4 \mathrm{e}^{\mathrm{fg}}$ & $892.33^{\mathrm{h}}$ \\
\hline $\mathrm{N} 2 \mathrm{P} 1$ & $12.1^{\mathrm{g}}$ & $76.33^{f}$ & $11.43^{\mathrm{a}}$ & $1.91^{\mathrm{a}-\mathrm{c}}$ & $22.6^{\mathrm{a}-\mathrm{c}}$ & $6.91^{\mathrm{g}}$ & $2351.0^{\mathrm{b}-\mathrm{e}}$ \\
\hline $\mathrm{N} 2 \mathrm{P} 2$ & $19.67^{\mathrm{a}}$ & $118.0^{\mathrm{a}}$ & $11.22^{\mathrm{ab}}$ & $1.91^{\mathrm{a}-\mathrm{c}}$ & $24.37^{\mathrm{a}}$ & $11.47^{\mathrm{a}}$ & $2360.5^{\mathrm{b}-\mathrm{d}}$ \\
\hline N2P3 & $13.85^{\mathrm{c}-\mathrm{g}}$ & $106.0^{\mathrm{a}-\mathrm{c}}$ & $10.90^{\mathrm{a}-\mathrm{c}}$ & $1.94^{\mathrm{ab}}$ & $23.47^{\mathrm{a}-\mathrm{c}}$ & $9.85^{\mathrm{b}}$ & $3045.5^{\mathrm{a}}$ \\
\hline $\mathrm{N} 2 \mathrm{P} 4$ & $12.29^{\mathrm{g}}$ & $90.0^{\mathrm{e}}$ & $10.40^{\mathrm{b}-\mathrm{d}}$ & $1.8^{b-f}$ & $19.49^{\mathrm{e}}$ & $6.96^{\mathrm{fg}}$ & $1930.5^{\mathrm{d}-\mathrm{f}}$ \\
\hline N3P1 & $14.92^{b-f}$ & $93.0^{\mathrm{de}}$ & $11.14^{\mathrm{a}-\mathrm{c}}$ & $1.82^{b-f}$ & $22.84^{\mathrm{a}-\mathrm{c}}$ & $8.44^{b-f}$ & $1787.16^{\mathrm{f}-\mathrm{g}}$ \\
\hline N3P2 & $14.47^{b-g}$ & $104.67^{b-d}$ & $10.71^{\mathrm{a}-\mathrm{d}}$ & $1.77^{\mathrm{c}-\mathrm{f}}$ & $22.44^{b c}$ & $9.34^{b-d}$ & $2149.67^{\mathrm{b}-\mathrm{e}}$ \\
\hline N3P3 & $15.21^{\mathrm{b}-\mathrm{e}}$ & $90.67^{\mathrm{e}}$ & $10.98^{\mathrm{a}-\mathrm{c}}$ & $1.91^{\mathrm{a}-\mathrm{c}}$ & $22.16^{\mathrm{cd}}$ & $7.99^{\mathrm{d}-\mathrm{g}}$ & $2170.16^{\mathrm{b}-\mathrm{e}}$ \\
\hline N3P4 & $15.12^{\mathrm{b}-\mathrm{e}}$ & $90.0^{\mathrm{e}}$ & $11.20^{\mathrm{ab}}$ & $2.0^{\mathrm{a}}$ & $22.58^{\mathrm{a}-\mathrm{c}}$ & $8.08^{\mathrm{c}-\mathrm{g}}$ & $2671.67^{\mathrm{ab}}$ \\
\hline N4P1 & $12.93^{\mathrm{d}-\mathrm{g}}$ & $67.0^{f}$ & $9.31^{\mathrm{e}}$ & $1.7^{\mathrm{f}}$ & $20.28^{\mathrm{de}}$ & $5.41^{\mathrm{h}}$ & $1951.16^{\mathrm{c}-\mathrm{f}}$ \\
\hline N4P2 & $16.64^{\mathrm{b}}$ & $111.0^{\mathrm{ab}}$ & $10.34^{\mathrm{b}-\mathrm{d}}$ & $1.93^{\mathrm{ab}}$ & $21.62^{\mathrm{cd}}$ & $9.56^{\mathrm{bc}}$ & $2168.33^{\mathrm{b}-\mathrm{e}}$ \\
\hline N4P3 & $12.5 \mathrm{f}^{\mathrm{g}}$ & $75.0^{f}$ & $10.73^{\mathrm{a}-\mathrm{d}}$ & $1.84^{\mathrm{b}-\mathrm{f}}$ & $24.2^{\mathrm{ab}}$ & $7.2^{\mathrm{fg}}$ & $2523.83^{\mathrm{a}-\mathrm{c}}$ \\
\hline N4P4 & $15.96^{b c}$ & $95.0^{\mathrm{c}-\mathrm{e}}$ & $11.03^{\mathrm{a}-\mathrm{c}}$ & $1.76^{\mathrm{de}}$ & $21.61^{\mathrm{cd}}$ & $8.18^{\mathrm{c}-\mathrm{g}}$ & $2424.16^{\mathrm{b}-\mathrm{d}}$ \\
\hline LSD at $5 \%$ & 2.59 & 12.12 & 0.96 & 0.143 & 1.89 & 1.48 & 572.98 \\
\hline $\mathrm{CV}$ & 10.38 & 7.68 & 5.4 & 4.65 & 5.26 & 10.9 & 16.99 \\
\hline
\end{tabular}

*Means followed by the same letter ( $\mathrm{s}$ ) in the same column are not significantly different at $5 \%$ level of significance. $\mathrm{FNPP}=$ fruit number per plant, TFNPP $=$ total fruit number per plot, AFW=average fruit weight, yield/plot= fresh fruit yield from the net plot area, yield/ha=fresh fruit yield in hectare base

\subsection{Economic Analysis}

The economic analysis of this study revealed that the economic optimum level of Okra fruit yield was obtained with application of $50: 37.5 \mathrm{~kg}$ of nitrogen and phosphorus per hectare with the highest net benefits of 153,958.16 ETB per hectare with the higher MRR (\%) values (3909.26) (Table 7). High net return from the foregoing treatments could be attributed to high yield and the low net return was attributed to low yield. From the economic point of view, it was apparent that $50 \mathrm{~kg}$ nitrogen with $37.5 \mathrm{~kg}$ phosphorus per hectare is more profitable than the rest treatment combinations. These results are further supported by Firoz (2009) who reported that the highest gross return and net return were obtained from $\mathrm{N}$ and $\mathrm{P}$ at the rates of $100 \& 120 \mathrm{~kg} / \mathrm{ha}$, respectively.

Table 9. Partial budget analysis

\begin{tabular}{lllllll}
\hline $\mathrm{N}$ & $\mathrm{P}_{2} \mathrm{O}_{5}$ & $\mathrm{TY}(\mathrm{t} / \mathrm{ha})$ & ATY/ha & TVC(B/ha) & NB(B/ha) & $\begin{array}{l}\text { Dominance } \\
\text { Analysis }\end{array}$ \\
\hline 0 & 0 & 6.88 & 6.192 & 0 & 73522.12 & \\
0 & 37.5 & 8.71 & 7.839 & 944.83 & 105517.3 & \\
50 & 0 & 6.91 & 6.219 & 1239.13 & 72822.99 & $\mathrm{D}$ \\
0 & 75 & 7.98 & 7.182 & 1889.66 & 91432.46 & $\mathrm{D}$ \\
50 & 37.5 & 11.47 & 10.323 & 2183.96 & 153958.2 & \\
100 & 0 & 8.44 & 7.596 & 2478.26 & 99123.86 & $\mathrm{D}$ \\
0 & 112.5 & 7.4 & 6.66 & 2834.49 & 80047.63 & $\mathrm{D}$ \\
50 & 75 & 9.85 & 8.865 & 3128.79 & 123853.3 & $\mathrm{D}$ \\
100 & 37.5 & 9.34 & 8.406 & 3423.09 & 114379 & $\mathrm{D}$ \\
150 & 0 & 5.41 & 4.869 & 3717.39 & 43344.73 & $\mathrm{D}$ \\
50 & 112.5 & 6.96 & 6.264 & 4073.62 & 70888.5 & $\mathrm{D}$ \\
100 & 75 & 7.99 & 7.191 & 4367.92 & 89134.2 & $\mathrm{D}$ \\
150 & 37.5 & 9.56 & 8.604 & 4662.22 & 117099.9 & $\mathrm{D}$ \\
100 & 112.5 & 8.08 & 7.272 & 5312.75 & 89809.37 & $\mathrm{D}$ \\
150 & 75 & 7.2 & 6.48 & 5607.05 & 73675.07 & $\mathrm{D}$ \\
150 & 112.5 & 8.18 & 7.362 & 6551.88 & 90370.24 & $\mathrm{D}$ \\
\hline
\end{tabular}

*TY=total yield tone/ha, ATY=adjusted total yield tone/ha, $\mathrm{TVC}=$ total variable cost in birr, $\mathrm{NB}=$ Nate benefit in birr, $\mathrm{D}=$ dominated

\section{Conclusion and Recommendation}

Achievements of maximum yield by crop rely on the application of sufficient level of fertilizers. In view of this, both growth parameters and yield of Okra plants were affected by application of N and P fertilizer rates. Generally, $\mathrm{N}$ fertilizer application at the rate of $50 \mathrm{~kg} / \mathrm{ha}$ and $\mathrm{P}$ fertilizer application rate of $37.5 \mathrm{~kg} / \mathrm{ha}$ would be preferred for 
Okra fruit production in the study area. Therefore increasing the rate of $\mathrm{N}$ and $\mathrm{P}$ fertilizer will lead to higher metabolic activities and consequently higher fresh fruit yield in Okra until $50 \mathrm{~kg} / \mathrm{ha}$ nitrogen and $37.5 \mathrm{~kg} / \mathrm{ha}$ phosphorus. So further refining below these nitrogen and phosphorus level will be important to minimize loss of nutrients. However, in order to give conclusive recommendation for the study area, similar field and economic feasibility studies need to be carried out for a number of seasons in different soils.

\section{Reference}

Abebe, Z., and H. Feyisa. 2017. "Effects of Nitrogen Rates and Time of Application on Yield of Maize : Rainfall Variability Influenced Time of N Application." International Journal of Agronomy 2017: 1-11. doi: $10.1155 / 2017 / 1545280$

Aladele, S.E., O.J. Ariyo, and R. De Lapena. 2008. "Genetic Relationships among West African Okra (Abelmoschus Caillei ) and Asian Genotypes ( Abelmoschus Esculentus ) Using RAPD.” 7(10): 1426-1431.

Baw, A.O., F. Gedamu, and N. Dechassa. 2017. "Effect of Plant Population and Nitrogen Rates on Growth and Yield of Okra [ Abelmoscus Esculentus ( L ). Moench ] in Gambella Region , Western Ethiopia." 12(16): 1395-1403. doi: 10.5897/AJAR2016.11856.

FAOSTAT. 2017. Economic and social Department. The Statistics Division. Major Food and Agricultural Commodities and Producers. http://faostat.fao.org/site/339/default.aspx.

Firoz, Z.A. 2009. “[Abelmoschus Esculentus.” Bangladesh J. Agril. Res. 34(December): 713-722.

Gemede, H.F., N. Ratta, G.D. Haki, A.Z. Woldegiorgis, and F. Beyene. 2015. "Nutritional Quality and Health Benefits of Okra ( Abelmoschus Esculentus ): A Review.” 25(1): 16-25.

Gomez K.A and Gomez A.A. 1984. Statistical Procedures for Agricultural Research. (2 ${ }^{\text {nd }}$ ed.), John Willey and Sons, New York, 657.

Hassan, M.A.M., and H.M. Ali. 2015. "The Nutritional Composition of Three Cultivars of Okra ( Abelmoschus Esculentus L .) Seeds Flour." World Journal of Dairy \& Food Sciences 10(2): 122-131. doi: 10.5829/idosi.wjdfs.2015.10.2.1150.

Hossain M. D. and Olasantan M. A. 2001. Year round okra production and economic return as influenced by spacing in Barisal region. Bangladesh J. Agri. Res. 25: 319-328.

J. Benton Jones, J. 2002. Agronomic Handbook: Management of Crops, Soils, and Their Fertility. Boca Raton London New York: CRC PRESS. doi: 2002073651

Khan, H., M. Khan, K. Rasul, A. Majeed, F.A. Safi, S. North, P.O.B. No, and S. Sharif. 2000. "Effect of Different Levels of Nitrogen Alone and in Combination with Constant Doses of Phospohorus and Potassium on Grwoth and Yield of Okra ( Abelmoschus Esculentus L .) Cv . T-13 under the Agro-Climatic Conditions of Mingora, Swat." Pakistan Journal of Biological Sciences 3(12): 2101-2104.

Khan, M.A., M. Sajid, Z. Hussain, A. Rab, K.B. Marwat, and S. Bibi. 2013. "How Nitrogen and Phosphorus Influence The Phenology Of Okra.” 45(2): 479-482.

Khandaker, M.M., T. Dalorima, R.P. Maiduguri, and N. Mat. 2017. "Effect of Different Rates of Inorganic Fertilizer on Physiology, Growth and Yield of Okra ( Abelmoschus Esculentus ) Cultivated on BRIS Soil of Terengganu." Australian Journal of Crop Science 11(07): 880-887. doi: 10.21475/ajcs.17.11.07.pne552.

Kumar, S., and J.P. Singh. 2015. "EF FECT OF PLANT GE OM E TRY AND NU TRI TION ON THE GROWTH AT TRIB - UTES OF OKRA [ Abelmoschus Esculentus ( L .) Moench ] CV . PUSA SAWANI." 4(June): 144-149.

Naheed, Z., A. Ayyaz, A. Rehman, N.A. Khan, S. Qayyum, F.S. Hamid, A. Waheed, S. Asghar, and M.S. Khan. 2013. "Agronomic Traits of Okra Cultivars under Agro-Climatic Conditions of Baffa." J. Mater. Environ. Sci. 4(5): 655-662.

Naim, A.H., and N.M. Abker. 2016. "Effects of Chicken Manure and Nitrogenous Fertilizer on Growth,Yield and Yield Components of Okra (Abelmoschus Esculentus (L.) Monech) under Rainfed Conditions.” 7(6): 594601.

Paththinige, S., R. Ranaweera Banda, and R. Fonseka. 2008. "Effect of Plant Spacing on Yield and Fruit Characteristics of Okra (Abelmoschus Esculentus)." Tropical Agricultural Research 20: 336-342.

Zibelo, H. 2016. "Effect of Inter-And Intra-Row Spacing on Growth and Yield of Okra [ Abelmoschus Esculentus ( L .) Moench ] at Humera , Northern." 6(3): 92-108. 